\title{
Do Human Care and Knowledge Management Practices Really Matter in Determining Worker Productivity? Perceptions of Supervisory Level Employees in Tea Plantation Sector in Sri Lanka
}

\author{
A. T. Gamage ${ }^{1}$ and W. P. R. Wickramaratne ${ }^{2}$ \\ ${ }^{1}$ Deputy General Manager, Kelani Valley Plantations PLC, Hayleys Plantations \\ Sector, Sri Lanka \\ ${ }^{2}$ Senior Lecturer, Department of Human Resource Management, Faculty of \\ Management, University of Peradeniya, Sri Lanka \\ 22Anuruddha1973@gmail.com
}

\begin{abstract}
The tea industry is still one of the dominant industries in Sri Lanka due to its vast impact on the economic and socio-cultural environment. However, this significance is gradually declining mainly because of lowering worker productivity. This current study explored whether the decreasing productivity in Sri Lankan Tea industry can be turned around and sustained by implementing human care and knowledge management practices that enhance tea estate workers' quality of life and quality of work life. Unstructured interviews with a random sample of 75 supervisory level managers of wellestablished tea plantation companies reported that a range of human care and knowledge management practices contribute to enhance worker productivity via enhanced quality of life and quality of work life. The findings provide implications to the social exchange and psychological contract theories whereas policy makers should implement proposed knowledge management and human care practices for enhancing the worker productivity.
\end{abstract}

Keywords: Human Care Practices, Knowledge Management Practices, Quality of Work-life, Quality of life, Worker productivity, Tea plantation industry

\section{Introduction}

Being the largest tea exporter with average revenue of 15 billion USD in the year 2015, Tea industry in Sri Lanka plays a significant role in country's economy with a contribution of approximately $4.2 \%$ to the Gross Domestic Production (GDP) and foreign exchange earnings (Central Bank of Sri Lanka, 2018; Gamage \& Wickramaratne, 2019). Moreover, tea is one of the main products exported with the rank of $4^{\text {th }}$ largest tea producer in the world and accounts for $55 \%$ of the total export revenue (Ehrhart \&
Madariaga, 2017). However, Sri Lanka is currently experiencing a loss of its dominance in the world market due to various reasons out of which strong competition and low worker productivity are the more significant factors. Consequently, there are declining trends in terms of contribution to country's GDP (Koththagoda \& Dissanayake, 2017), critical productivity indicators (Kelegama, 2010; Perera, 2017; Gamage \& Wickramaratne, 2019; Gamage, 2010; Munasinghe, 
Deraniyagala, Dassanayake and Karunarathna, 2017) ) and decreasing competitiveness in the global tea market (Perera, 2017; Hilal, 2020). In this context, Sri Lanka has become the country with the lowest productivity compared to major competitors such as Kenya and India (Gamage \& Wickramaratne, 2019). Tea industry in Sri Lanka can be divided into two subsets, such as regional plantation companies (RPCs) and tea small holders, out of which these critical issues are mainly with RPC sector. As a high labor intensive industry (Gamage \& Wickramaratne, 2019; Silva, 2018) RPCs need to change its traditional land and labor usage and management models to enable RPCs to solve the current crisis of tea industry, especially low productivity (Perera, 2017; Koththagoda \& Dissanayake, 2017).

The above discussed issues in the tea plantation industry have led to serious social, economic and environmental consequences. In terms of social aspects, lack of adequate financial resources has resulted in insufficient attention paid on uplifting the wellbeing of the entire plantation community and invest in high tech machineries and equipment. The social development of tea estate workers and their productivity has created a chronic vicious cycle, requiring a sustainable solution incorporating all the beneficiaries of this sector (Dishanka \& Ikemoto, 2014). Findings of Mwaura and Muku (2007) suggested that in order to improve the labour productivity, the welfare of farmers should be improved in tea plantation industry. It revealed that inadequate human care initiatives, poor socio- economic condition of workers, noncompetitive \& traditional work norms, lack of cooperativeness between workers and management have adversely affected the labour productivity. It has been observed that declining productivity indicators and lack of best management practices led to create slow progress on industry performances over global competition and need of open up different alternative approaches has become a mandatory requirement. It has also been highlighted in previous studies that different human resource approaches to uplift the workers' social status and resolving social obligations related to the social well-being of workers, contributed positively on increasing present low productivity levels (Kodithuwakku \& Priyanath, 2007; Dishanka \& Ikemoto, 2014; Savarimuthu \& Rachael, 2017; Gamage \& Wickramaratne, 2019).

Based on the above discussed issues and related negative consequences suggest that the existing traditional Human Resource Management (HRM) policies and practices in the tea plantation industry are not adequate for dealing with the problem of low worker productivity and its negative consequences on economy, society and the environment. Therefore, the objectives of this study are twofold: to verify the findings of a prior study conducted by the authors based on the senior level managers to identify productivity enhancing human care and knowledge management practices for a sustainable tea plantation industry and to propose a productivity enhancing HRM model applicable to the tea plantation industry. Thus, the study is expected to make a policy implication 
to the tea plantation industry in terms of proposing human care and knowledge management practices that enhance the worker productivity and overall productivity as well as to make a theoretical contribution by proposing a productivity enhancing HRM model to the tea plantation industry which can be implemented following a survey conducted with a representative sample of plantation employees.

\section{Literature Review}

\section{Evolution and current trends of tea industry in Sri Lanka}

Tea was introduced to Sri Lanka after the Coffee Leaf Rust disease in the 19th century whereas commercial cultivation of tea began in 1876 by a Scottish planter, James Taylor. Tea is an industry in which Sri Lanka has established a global reputation as 'Ceylon Tea', due to its high quality. Tea industry in Sri Lanka has more than 150 years of great history as of today and currently this industry supports economically for a population of over 2 million Sri Lankans including the active workforce. This is the biggest industry in terms of providing employment which accounts for $10 \%$ of the total population in Sri Lanka (Thushara, 2015; Central Bank of Sri Lanka, 2018; Silva, 2018). Sri Lanka is the third in the world in terms of land usage for tea (Central Bank of Sri Lanka 2018; Gamage \& Wickramaratne, 2019), fourth biggest tea producer (Silva, 2018; Central Bank of Sri Lanka) and $3^{\text {rd }}$ largest tea exporter (Sri Lanka Tea Board Annual Report, 2018). It is the highest tea export revenue earner, largest orthodox tea producer and exporter as well as largest value added tea exporter (Central bank of Sri Lanka, 2018; Sri Lanka Customs report, 2018). For more than a century, Sri Lanka's tea industry has been the backbone of the island's economy contributing $40 \%$ of export revenue and $30 \%$ of the agricultural labor force (Gamage \& Wickramaratne, 2019). In spite of the dominant role of tea industry in the Sri Lankan economy, recent statistics indicate that its contribution to the economy is gradually declining (Thushara, 2015) mainly because of the decreasing the worker productivity.

\section{The crisis of declining productivity of the tea industry in Sri Lanka}

Worker productivity is one of the important and key management topics with significant research attention from scholars and it is considered as a primary mechanism to enhance organizational success. Thus, understanding and knowing the key factors of the particular business which influence its productivity is vital to ensure long term performance. Employee productivity is an assessment of the efficiency of a worker or group of workers ( Hill, Jones, \& Schilling, 2014; Jalal, 2016). Worker productivity and efficiency in tea plantations are crucial in the determination of cost of production, profitability, quality of tea, and volume of production (International Labour Organization, 2002; Dishanka \& Ikemoto,2014).Therefore, there is a significance of analyzing the worker productivity since productivity is a determining factor of long term survival of a firm (Sauermann, 2016) and it's a factor affecting the competitiveness of a firm through cost 
reductions and improvement of the quality of output (Baily, Farrell, Greenberg, Henrich, Jinjo, Jolles \& Remes, 2005; Hill, Jones, \& Schilling, 2014; Jalal, 2016, 2014; Jalal, 2016).

Apart from these key benefits, productivity indicators of tea industry gives an idea about the efficiency level of utilization of limited resources in the current crisis of low worker productivity due to low intake per harvester and high cost of production. Cost of labour represents approximately $65 \%$ of the total cost of production in tea industry in Sri Lanka (Sri Lanka Tea Board, 2010; Gamage \& Wickramaratne, 2019), which is higher than that of other tea producing countries such as Kenya, China and India. This situation has shed light on industry key players to seriously contemplate on increasing worker productivity parameters to sustain the industry. Therefore, the challenge face by the tea industry in Sri Lanka is to increase productivity and quality and add more value to the tea so as to offset the higher cost of production. Human care practices such as improving levels of health \& nutrients, living environment, employee safety and protection measures and knowledge management initiatives including exchanging expert knowledge into sustainable business development can be used for the motivation and engagement of existing workforce in tea plantations. That is, more engaged and motivated workers will produce comparatively higher outputs with high quality so that the productivity will be increased (Dishanka \& Ikemoto, 2014; Sauermann, 2016).
Moreover, economic variables such as investment in new technology and innovation, education, health and social divergence are also determinants of productivity (Sharpe, 2004). Organizations' ability of getting these parameters satisfied would probably motivate the workers and thus improve individual's productive capacity (Khan,Shaw, \& Hussain , 1991; Gopaldas \& Gujral, 2002; Jalal, 2016). Therefore, the firm's investment on developing employees' skills through promoting training as well as educational programmes and welfare is essential as it enhances their abilities and satisfaction level and creates a productive workforce (Warr \& West, 2004; Sharma \& Sharma, 2014; Dishanka \& Ikemoto, 2014).

In addition to the socio-economic factors, health related factors also impact on productivity. For example, a study has revealed that there is a strong association between anemia (iron inadequacy and insufficient hemoglobin levels) and productivity (Selvaratnam, Pathmeswaran \& De Silva, 2011). This is evident in Sri Lankan tea plantation sector, since the most critical health issue is anemic workers who are naturally contributing to low productivity. Consequently, tea estate managers are taking different approaches to identify those workers and treat them under iron supplementary programmes.

\section{Poor Quality of life $(Q L)$ and Quality of Work-life (QWL) of tea plantation workers}

Quality of life (QL) is a concept of economics, sociology and political science which encompasses an 
individual's spiritual (emotional), social and physical well-being) whereas Quality of work life (QWL) is a mix of work place strategies, processes and environment, which stimulates employee's job satisfaction (Considine, 2002; (Ruževičius, 2012). QWL also depends on work conditions and the efficiency of the organization (Considine, 2002; Ruževičius, 2014). More elaborated definition explained by James, (1992), that, Quality of Work-life can be defined under three different perspectives. Firstly, QWL as a target which is to improve the working place and make the working environment more comfortable. Secondly, QWL as a process which is to combines the needs of the employees and the goals of the organization. Thirdly, QWL as a philosophy which is to value individual as an asset that can be nurtured through knowledge and experience. An individual's quality of working life directly influences the quality of his or her life value whilst the quality of life is determined by his or her work environment (Schoepke, 2003; Kajzar \& Kozubkova, 2007; Ruževičius, 2014). Therefore, these two concepts are interrelated in real working environment (Considine, 2002). This fact is further supported by the behavioral components of quality of life towards improvement in quality of work life and their influence towards individual's desire to contribute to strengthening the organization's productivity (Leitão, Pereira \& Gonçalves, 2019). Both QL and QWL together act as a factor to motivate employees, to enhance their commitment towards the organization and also to improve their performance (Suri \& Baber, 2019).
The QL and QWL are deemed to be lower in the tea plantation sector in Sri Lanka than that of other sectors. The resident workers of tea estates are geographically and socially isolated from the other sectors of the economy for over 150 years (Jayawardena, 1984). These resident workers emigrated from South India in the late nineteenth century and have been categorized as a separate social entity known as 'estate population' characterized by a unique set of attributes based on their culture and socio-economic conditions (Dishanka \& Ikemoto, 2014). Their physical and psychological well-being in their living and working environment is at a very low level. This will lead to lower the commitment, engagement and work motivation of workers the ultimate outcome of which will be low productivity of workers in terms of quantity and quality of their work. However, in a recent study, we found that the estate workers' productivity is increased with the increase of their QL and QWL (Gamage \& Wickramaratne, 2019).

\section{Sustainability of Tea Industry}

Since tea industry in Sri Lanka plays a major role in country's socio-economic and environmental aspects, the impact of tea industry on all sustainability parameters are significant. Even though, the tea industry as one of the main contributor for foreign exchange earner in the country with approximately $15 \%$ contribution to the national income (Central Bank of Sri Lanka, 2018), at present tea plantation industry in Sri Lanka facing critical challenges to enhance profitability and also in terms of sustainability of the 
sector while managing the high cost of production, decreasing land use efficiency and finding solutions for low labor productivity (Koththagoda \& Dissanayake, 2017; Central Bank of Sri Lanka, 2018). The potential of increasing the small holder contribution to national outputs of the country and the tendency of plantation workers becoming out-growers, it is a current need that Sri Lankan tea sector should expose too many changes for remain sustainable in the industry (Wal, 2008). The sustainability aspect of the tea industry in terms of social parameters, poor living and working conditions, inadequate facilities including housing, drinking water and other sanitation facilities will lead to lower the performances of the workforce (Wickremasinghe and Cameron, 2002; Wal, 2008).

Wal, 2008, further elaborated that, in terms of environmental sustainability the tea industry in India and Sri Lanka - more than in the other countries studied - has impacted the environment negatively through high agrochemical usage and deforestation. The contribution towards environmental sustainability is significant in several attempts made by key multi-national companies in tea industry in Sri Lanka (Wal, 2008; Gamage, 2010). They further explained that, these companies have adopted a more systematic triple bottom line reporting method which covers the full spectrum of economic, environmental and social impacts. Additionally, most of the factories are now entirely powered by renewable sources of timber and in the process of developing a system of establishing their carbon balance sheet or footprint, with the aim of reducing emissions of global greenhouse gases. The effect of climate change and impact of environmental sustainability of tea industry in Sri Lanka is well explained by Karunaratne, Nissanka, Punyawardena and Gunawardena, 2015. As per the findings, the technology of Geographic Information Systems (GIS) is used extensively in vulnerability mapping and several attempts by key players of tea value chain have been made so far to identify agriculturally vulnerable hot spots within Sri Lanka. It also facilitates for future planning purposes in tea industry, ensuring sustainability of the tea sector in the future as well Eriyagama, Smakhtin, Chandrapala and Fernando (2010).

Way forward, sustainable growing practices and organic farming methods both play a crucial role and have an intimate relationship for successful performance in the industry. This is why signature teas of some countries including certified organic varietals, bio-diversely grown and sustainably hand-harvested teas have high value market in the global tea trade (Tessa, 2019).

\section{Human Care Practices (HCPs) and Knowledge Management Practices (KMPs) in tea plantations}

Developing a human resource management system holds greater promise for productivity improvement than developing the technical systems (Aponso, 2000; Dishanka \& Ikemoto , 2014). Responding to this claim, in a recent study of senior plantation managers, authors have proposed two bundles of sustainable human resource 
management practices: Human Care Practices (HCP) and Knowledge Management Practices (KMP) for the tea plantation industry to address the issue of declining productivity (Gamage \& Wickramaratne, 2018; Gamage \& Wickramaratne, 2019).

Some other studies have proposed individual HCPs. For example, safety, satisfaction, growth \& development related practices (Ahmad, 2013), welfare and practices related to uplifting employee knowledge and education levels (Arunatilake, 2000; Arunatilake, 2002; Priyantha \& Kodithuwakku, 2007 and Gamage \& Wickramaratne, 2018) as well as the practices related to improve healthy and safe working environment, safety and protective working facilities, participation in decision making and employee empowerment, creating culture of openness regarding decision making, encouragement of initiatives and creativity, opportunities to develop skills and initiatives to have better work-life balance (Lowe, 2000). In addition, there are various programmes to improve health and nutrient status of workers, child care facilities, estate housing and other facilities related to sanitation and other social support systems as well as physical infrastructure support in the estate sector which has a positive impact on labour performance (Arunatilake 2002; Priyanath \& Kodithuwakku, 2007). The ultimate outcome of providing these HCPs would be developing a "plantation family" that has fulfilled their basic requirements. This will enhance the productivity levels and performance expected by employers as well as to build up a strategic relationship between management and workforce as major partners in the tea plantation community for the mutual benefits of both parties and sustainable development of the industry (Rajaurai, 2015; Redmond, 2015; Savarimuthu and Rachael, 2017; Gamage \& Wickramaratne, 2018 and Gamage \& Wickramaratne, 2019).

In addition to different human care practices, knowledge management and employee education related initiatives lead to higher productivity of employees in tea industry (Sharpe, 2014; Gamage \& Wickramaratne, 2019). For example, Gamage \& Wickramaratne (2019) suggest that the improved knowledge levels, positive attitudes towards gaining advanced skills, use of advanced technology to capture and sharing knowledge for development initiatives will go a long way to upgrade an average productive worker in to a top performer.

In sum, the review of extant literature implies that some individual human care practices and knowledge management practices lead to enhanced worker productivity in the tea plantation industry. However, there are no prior empirical studies found that has proposed bundles of those practices that lead to higher worker productivity. Consequently, prior studies do not guarantee that the productivity of workers will be increased when the individual human care practices and knowledge management practices proposed by prior studies are implemented together. 


\section{Study Framework}

The psychological contract theory, introduced by Argyris (1960) suggests that the psychological contract as a form of social exchange vested upon the need to understand the role of subjective and indeterminate interactions between two parties: employer and employee. The findings of Rousseau (1989) also explained the reciprocity nature in psychological contract as an individual's beliefs regarding reciprocal obligations set in the context of the employer/employee relationship and to exchange the benefits by both parties. As an extension of the psychological contract theory, social exchange theory (Blau, 1964) suggests that social exchanges linked with relational obligations which are unspecified and fulfillment of which depends on trust because it cannot be enforced in the absence of a binding contract. Employees tend to take a long-term approach to social exchange relationships at work, with the pattern of reciprocity over time determining the perceived balance in exchanges (Blau, 1964; Rousseau 1989; Lawler \& Thye, 2006; Savarimuthu \& Rachael, 2017).
By integrating the literature reviewed in this study with these two theories, it's expected that the quality of work life and quality of life of tea plantation employees are enhanced through human care and knowledge management practices. That is, employees are benefitted with human care and knowledge management practices which results in their emotional, social and physical wellbeing (quality of life) and feeling of having a comfortable working environment (quality of work life). Consequently, as suggested by Social Exchange and Psychological Contract Theories, they develop a sense of an obligation to reciprocate by increasing their productivity. Therefore, we can reasonably expect that the quality of life and quality of work life explains the relationships of human care and knowledge management practices with worker productivity. Furthermore, the review of literature reveals that the human care and knowledge management practices are directly related to the worker productivity despite the reciprocity norm. Based on these theoretical arguments and the results of previously conducted researchers' qualitative study of senior plantation managers (Gamage and Wickramaratne, 2018), the following conceptual framework is proposed. 


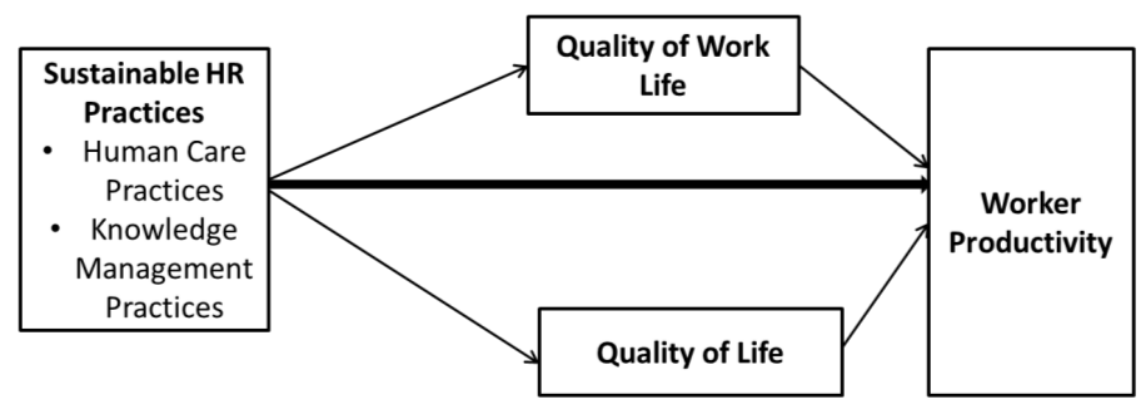

Figure 01: Study Framework

Source: Gamage and Wickramaratne, 2018

\section{Materials and Methods}

\section{Data collection procedure}

The study employed a qualitative approach which relied mainly on responses to unstructured interviews with supervisory level managers whereas open-ended on-line survey was employed to supervisory level managers who are geographically dispersed. Qualitative research methodology was adopted mainly to uncover trends in thought and opinions related to the selected research topic and dive deeper into the problem. The selected random sample consists of 75 supervisory level managers who represented Executives, Assistant Estate Managers, and other junior and senior executive level employees who are presently working in wellestablished tea plantations. In total, there were 44 tea estates in the sample. The qualitative study consisted four main questions as given below.
Q.1 What are the sustainable HR practices which have a significant impact on enhancing productivity levels in plantation industry?

Q.2 What is your personal opinion about the relationship of these sustainable HR practices with the quality of life and quality of work life of workers as well as with worker productivity?

Q.3 How do you elaborate the role of quality of work-life of the human resource segment in plantations towards enhancing the productivity levels?

Q.4 How do you elaborate the role of quality of life of plantation community (including workforce) towards enhancing the productivity levels?

Participants were assured the anonymity of responses, the interview procedure was explained and obtained the consent for their voluntary participation prior to their participation. Average duration 
allocated for each interview was 30 minutes and additional 15 minutes per participant were given to elaborate their open views and further clarifications. The on-line questionnaire was divided in to two main sections: general information about the participants such as their experience in plantation \& their demographic information and the open ended questions within the predetermined structure for clustering productivity enhancing human care practices and knowledge management practices. The participants were asked to prioritize human care and knowledge management practices according to the relative importance (Refer appendix for the on-line questionnaire). The human care practices were clustered during the questionnaire development stage based on the pre-determined categories by considering the first author's practical exposure as a senior plantation manager and by considering the authors previous research findings (Gamage \& Wickramaratne, 2018 and Gamage \& Wickramaratne, 2019). Similarly, the knowledge management practices (Evans \& Ali, 2013; Evans, Dalkir, \& Bidian, 2014; Serenko \& Dumay, 2015) and knowledge management practices (Nonaka \& Peltokorpi, 2006; Evans et al., 2014; DeLone \& McLean, 2016) were further refined by using the previous research findings. The qualitative data was classified, summarized and tabulated manually with the content analysis technique. Pre-defined codes with short phrases were developed by the use of previous research findings and industry experience of the authors of this study.

\section{Reliability and Validity}

The reliability of the information collected was assured by replicating the questions in the questionnaire for same information using various patterns and such information was supported with the findings from multiple sources such as printed and on-line publications, industry related research papers and participatory observations. Reliability was also assured by building trust relationships with the respondents and staying in the research setting for a long period of time as well as by keeping the accurate and detailed field notes. The on-line link via Google drive has been forwarded to their respective emails and the feedback was recorded anonymously to maintain the higher level of accuracy. The validity was assured by checking how well results correspond to established theories and other measures of the same concepts. Data collection was triangulated by selecting different locations and multiple individuals.

\section{Findings}

Based on the responses to the on-line questionnaire and unstructured interviews human care best practices categories were grouped in to the predetermined structure considering the researchers' experience in tea industry whereas knowledge management best practices categories were grouped by considering the key steps of knowledge management cycle relevant to the tea industry. Managers from most junior to senior level stressed that the identified key human care and knowledge management practices are the best to enhance the worker productivity levels in tea plantation industry in Sri Lanka. 
According to the feedback of participants, $90 \%$ of the total has mentioned that, sustainable HR practices including human care initiatives such as health and nutrients, activities related to upgrading the conditions of living environment of workers, enhancing employee capacity through encouraging savings and promoting additional income sources and activities related to youth empowerment has significant impact on enhancing worker productivity levels. Also, they have mentioned that, knowledge management initiatives as sustainable HR practices such as knowledge sharing and exchange, advance knowledge storing and reviewing facilities have significant impact on worker productivity in tea plantation industry in Sri Lanka.

They further highlighted that, identified best human care and knowledge management practices are directly related to the quality of life and quality of work-life which in turn effect on uplifting the levels of worker productivity. Results were further verified through the interviews responses of different layers of executive and managerial personals in tea industry who revealed that that the motivated and highly engaged workers stimulated from best human care and knowledge management practices are producing more quantitative and qualitative outputs in terms of intake per harvester, yield per hectare per worker and quality of green tea leaves harvested. They further highlighted with their observations that, identified best knowledge management practices have direct influence on worker productivity. Following table presents a summary of human care and knowledge management practices identified in this study.

Table 1: Sustainable Human Care Practices (HCPs) and Knowledge Management Practices (KMPs)

\begin{tabular}{|l|l|}
\hline \multicolumn{1}{|c|}{ Human Care Practices (HCPs) } & \multicolumn{1}{|c|}{$\begin{array}{c}\text { Knowledge Management Practices } \\
\text { (KMPs) }\end{array}$} \\
\hline Living Environment & Collection and Capturing \\
\hline Housing facilities & $\begin{array}{l}\text { Social and professional network for the } \\
\text { information collection }\end{array}$ \\
\hline Access to clean water & $\begin{array}{l}\text { Capturing knowledge by frequent } \\
\text { discussions }\end{array}$ \\
\hline Sanitation facilities & $\begin{array}{l}\text { Use of advance technology to capture } \\
\text { critical data and transfer these data in to } \\
\text { meaningful information }\end{array}$ \\
\hline Access roads for residence & $\begin{array}{l}\text { IT based online system to capture the } \\
\text { knowledge }\end{array}$ \\
\hline Facilities with community centers & Classify, Organize and Storing \\
\hline Health and Nutrition & $\begin{array}{l}\text { Advanced IT based data and information } \\
\text { storing facilities }\end{array}$ \\
\hline Zero anemia programmes & $\begin{array}{l}\text { Advanced and new technological } \\
\text { support for data classification which }\end{array}$ \\
\hline
\end{tabular}




\begin{tabular}{|c|c|}
\hline Human Care Practices (HCPs) & $\begin{array}{c}\text { Knowledge Management Practices } \\
\text { (KMPs) }\end{array}$ \\
\hline & $\begin{array}{l}\text { facilitate for speedy decision making } \\
\text { process }\end{array}$ \\
\hline Maternal care initiatives & $\begin{array}{l}\text { Development of central knowledge hub } \\
\text { and storing all relevant knowledge in this } \\
\text { central point }\end{array}$ \\
\hline Child care programmes & $\begin{array}{l}\text { Adequate use of new technology in } \\
\text { multiple sources }\end{array}$ \\
\hline Medical care facilities & Sharing \\
\hline $\begin{array}{l}\text { Vaccination programmes for workers } \\
\text { and children }\end{array}$ & $\begin{array}{l}\text { Development of e-learning facilities for } \\
\text { knowledge sharing }\end{array}$ \\
\hline Safety and Protection & $\begin{array}{l}\text { Use of L \& D module through HRIS for } \\
\text { sharing expert and advanced knowledge }\end{array}$ \\
\hline $\begin{array}{l}\text { Adequate and qualified safety and } \\
\text { protection staff }\end{array}$ & $\begin{array}{l}\text { Expand the opportunities for On-The Job } \\
\text { (OJT) facilities }\end{array}$ \\
\hline $\begin{array}{l}\text { Proper facilities and adequate safety and } \\
\text { protective equipments }\end{array}$ & $\begin{array}{l}\text { Development of internal talent pool for } \\
\text { sharing expert knowledge }\end{array}$ \\
\hline $\begin{array}{l}\text { Necessary training on occupational } \\
\text { safety and protection }\end{array}$ & $\begin{array}{l}\text { Development of a culture for learning by } \\
\text { self, starting from the senior } \\
\text { management layer in the estates }\end{array}$ \\
\hline $\begin{array}{l}\text { Occupational safety and protection } \\
\text { policy implementation }\end{array}$ & Access and Use/ Review \\
\hline Employee Capacity Building & $\begin{array}{l}\text { Introducing dash board system for easy } \\
\text { access to data base and for frequent } \\
\text { reviews }\end{array}$ \\
\hline $\begin{array}{l}\text { Training and awareness on household } \\
\text { cash management and savings }\end{array}$ & $\begin{array}{l}\text { System to exchange internal expertise } \\
\text { and their knowledge with other } \\
\text { employees }\end{array}$ \\
\hline $\begin{array}{l}\text { Micro financing facilities through estate } \\
\text { worker housing cooperative societies for } \\
\text { small scale businesses }\end{array}$ & $\begin{array}{l}\text { More exposure to success stories from } \\
\text { other countries through foreign training } \\
\text { opportunities }\end{array}$ \\
\hline $\begin{array}{l}\text { Encouraging to start own family } \\
\text { businesses and cultivate their own home } \\
\text { gardens for self-satisfaction }\end{array}$ & $\begin{array}{l}\text { Development of need base annual } \\
\text { training calendar to cover all the layers } \\
\text { in human resource base }\end{array}$ \\
\hline Education and Development & $\begin{array}{l}\text { Use of advanced and new technological } \\
\text { support for easy access and review of } \\
\text { knowledge }\end{array}$ \\
\hline $\begin{array}{l}\text { Facilitate and assist talented children in } \\
\text { plantation families to continue their } \\
\text { studies by providing scholarships }\end{array}$ & Value Creation \\
\hline $\begin{array}{l}\text { Promoting talented children in plantation } \\
\text { families for higher education } \\
\text { opportunities }\end{array}$ & $\begin{array}{l}\text { Providing more opportunities for higher } \\
\text { education facilities to capture advance } \\
\text { technical knowledge to enhance }\end{array}$ \\
\hline
\end{tabular}




\begin{tabular}{|c|c|}
\hline Human Care Practices (HCPs) & $\begin{array}{c}\text { Knowledge Management Practices } \\
\text { (KMPs) }\end{array}$ \\
\hline & $\begin{array}{l}\text { competitive edge of employees specially } \\
\text { management }\end{array}$ \\
\hline $\begin{array}{l}\text { Expanding the limits of conventional } \\
\text { recruitment process and open } \\
\text { opportunities on management positions } \\
\text { for talented youth in plantation } \\
\text { community }\end{array}$ & $\begin{array}{l}\text { Developing rewards system based on } \\
\text { knowledge value creation process }\end{array}$ \\
\hline Youth Empowerment & Promote innovations and creativity \\
\hline $\begin{array}{l}\text { Providing opportunities and guiding } \\
\text { youth in plantations for vocational and } \\
\text { skills development programmes }\end{array}$ & $\begin{array}{l}\text { Building more viable relationship with } \\
\text { higher education and R \& D institutes }\end{array}$ \\
\hline $\begin{array}{l}\text { Engaging talented youth in to } \\
\text { development programmes in estates }\end{array}$ & Sustainability \\
\hline $\begin{array}{l}\text { Providing opportunities for leadership } \\
\text { development programmes }\end{array}$ & $\begin{array}{l}\text { Promoting higher studies to gain } \\
\text { necessary technical competencies }\end{array}$ \\
\hline \multirow[t]{3}{*}{$\begin{array}{l}\text { More training opportunities for other } \\
\text { languages and living skills }\end{array}$} & $\begin{array}{l}\text { Re-structuring recruitment process to } \\
\text { capture and retain top talent to } \\
\text { management layer }\end{array}$ \\
\hline & $\begin{array}{l}\text { Mapping the competencies based on the } \\
\text { positions in organizational hierarchy }\end{array}$ \\
\hline & $\begin{array}{l}\text { Development of talent pool and } \\
\text { connectivity in to succession plan in the } \\
\text { organization }\end{array}$ \\
\hline
\end{tabular}

Source: Interview Data, 2018

\section{Discussion}

The findings of this study were supported with the research findings, theories and models developed through various research. These findings related to human care initiatives as sustainable HR practices and worker productivity was well supported with the findings of a previous study conducted by the authors based on senior level plantation managers (Gamage and Wickramaratne, 2018; Gamage and Wickramaratne, 2019) as well as previous research by Gupta (2016). They argued that, healthy working environment, motivational climate, work redesign, sense of accomplishment and enthusiasm at work place has great impact on satisfy their important personal needs in terms of power and growth which make them perceive democratization of their work place which will enhance their creativity $\&$ innovativeness and finally add value to enhance their productivity levels. The findings were further strengthening by previous research findings related to knowledge management initiatives and worker productivity. Kara, et. al. (2018); Bophela \& Govender (2015) and Zin (2004) explained that, more than pay and benefits, growth and development have great impact on employees' commitments on organizational performances. They further explained, 
leadership style adopted by the managers and influence from employee support services to fulfill their social needs and upgrade knowledge levels has impact on enhancing quality of work-life and satisfied employees will produce more outputs (Omotayo, 2015).

Further, $91 \%$ and $92 \%$ of participants were responded respectively on the strong relationship between human care and knowledge management initiatives as sustainable HR practices and quality of work-life and quality of life with worker productivity. The findings were well supported with the previous studies of Omotayo (2015); Kaur (2016), that without adequate care about how knowledge is managed and less care on developing human resources. This argument is further supported with the findings of Savarimuthu \& Rachael (2017) that, organizations will not be operating optimally and this will result in the ineffective and inefficient creation and delivery of products and services. This critically explained the significance of the relationship between human care and knowledge management practices and worker productivity in an organization. The findings were further witnessed with the literature that, less attention on human care and knowledge management will lead to lack of quality in work-life, make inefficient and ineffective utilization of human resource of the organization, which is what ultimately leads to the demise of the organization due to poor productivity levels (Cullinane \& Dundon, 2006; Savarimuthu \& Rachael, 2017). Omotoyo (2015); Gamage \& Wickramaratne (2019) further argued that, if the organizations not pay proper care and attention about how knowledge is managed, optimum level operation will not be practical and resulted with ineffective and inefficient delivery of outputs and finally end up with poor productivity levels.

According to the impact of quality of work-life and quality of life on enhancing worker productivity levels, $84 \%$ of participants were responded positively. The findings were well supported with the witness of previous studies that, understanding importance of applying best knowledge management practices (KMPs) and human care practices (HCPs) has direct impact on enhancing the quality of work-life and quality of life of employees and improve their level of motivation and engagement (Omotoyo, 2015).

Elaborating the relationship between sustainable HR practices and worker productivity, highly engaged and motivated employees due to application of best human care initiatives will produce more outputs and finally end with higher productivity levels. The reliability of research findings were witnessed with the social exchange, reciprocity and psychological contract theories, which explain the relationship between sustainable human resource management and worker productivity. The early approaches of Argyris (1960), on psychological contract was, to conceptualize the theory as a form of social exchange. Anyhow, psychological contract is emerging as a newly arousing organizational term that interprets the fulfillment and nonfulfillment of organizational relationships in terms of mutual 
obligations, expectations and promises (Savarimuthu \& Rachael, 2017).

As per the explanation of logic behind on social exchange and obligatory theories and it's applicability to the plantation workers were witnessed with the research findings. When the workers obtained various support by way of human care and knowledge management practices such as facilities and opportunities, the workforce will motivate and in turn motivated workers enhance their productivity to reciprocate for the support they received from the company. The above explanation of the relationship between worker productivity and sustainable HR practices was supported with further studies of Irvine (2009); Savarimuthu \& Rachael (2017) that, applying human care and knowledge management best practices in an organization, will increase the level of engagement and strengthen the relationship between employer and employee and thereby will enhance the level of confidence and feeling of attachment in mind of each other.

An empirical studies have also indicated that the employee engagement is associated with psychological contracts (Masson, Royal, Agnew \& Fine, 2008; Bal, Kooij, \&DeJong, 2013; Chang, Hsu, Liou, \& Tsai, 2013).This will help to behave and reciprocate their mutuality towards each other and contribute to the efficiency of the employees and thereby productivity of the organization (Lodha \& Pathak, 2017; Savarimuthu \& Rachael, 2017). Rousseau (1989) explained this relationship as a psychological agreement and as the beliefs that are held by an individual regarding what they owe the organization, and what the organization owes them. He further argued that, relational contract establishes and maintains a relationship between employee and employer, involving monetizable and nonmonetizable exchanges such as loyalty to the organization and recognition towards hard work (Rousseau, 1990). The constructive arguments on above previous studies help to elaborate the findings of research under review that, in tea plantations by applying human care best practices, workers and plantation communities feel comfortable on their life styles towards uplifting the level of quality of life, which brings them to psychologically relaxed mindset to contribute optimally to produce best outputs. Furthermore, applying knowledge management best practices will build up their level of confidence towards enhance the level of quality of life, in order to face various challenges successfully while on work. Both ways help to develop more engaged and committed workforce in tea plantations and finally to add value to increase the level of productivity.

The above argument is well supported with the previous studies that, fulfillment of employer promises, obligations, and commitments increases employee engagement which has ultimate impact on the firm's productivity (Coffman \& GonzalezMolina, 2002). This fact was counter argued with the support of logic behind psychological theory by Cullinane \& Dundon (2006); Redmond (2015) and it was empirically demonstrated that an increase in psychological contract fulfillment is related to an increase in 
employee engagement and ultimately to enhance employee productivity.

All social exchange theories treat social life as involving a series of sequential transactions between two or more parties (Mitchell, Cropanzano, \& Quisenberry, 2012). Chang et al. (2013); Bal et al. (2013); Redmond, (2015); Gamage \& Wickramaratne, (2019) empirically demonstrated the above fact with their research findings. It was clearly defined based on the findings from research under review by authors, that an increase in psychological contract fulfillment in terms of benefits for employee from different human care activities and knowledge management initiatives in tea plantations and benefits to the employer in terms of increase in outputs qualitatively and quantitatively, is related to an increase in employee engagement and ultimately to enhance employee productivity in the industry.

\section{Conclusion}

The main factors identified under best HCP and KMP, which represent as sustainable HRM practices in the proposed HRM model in tea industry in Sri Lanka has great impact on critical worker productivity indicators such as output per harvester, cost per worker. This proposed model critically explained the importance of practical HRM initiatives beyond the conventional HRM practices and the validity of such practices towards enhancing worker productivity. Furthermore, the proposed model can use as a value addition to conventional HRM models apply in other industries as well. In conclusion, total HRM approach in tea industry in Sri Lanka is a combination of conventional HRM practices and sustainable HRM initiatives such as best HCP and KMP, which has a great impact on worker productivity indicators.

\section{Policy Implications}

This study provides some important policy implications. The tea plantation sector should go beyond the traditional human resource management practices and implement sustainable human care and knowledge management practices to sustain the industry. In implementing these sustainable practices, the central focus should be quality of life and quality of work life of employees so that the workers will develop an obligation towards the firm based on the premise of reciprocity explained by the Psychological Contract and Social Exchange theories. Consequently, they will enhance their levels of productivity. To generate the expected results, each of these proposed practices should be implemented as a bundle.

\section{Limitations and Directions for Future Studies}

The particular research findings are based on a qualitative study with the randomly selected seventy five plantation managers including executives, junior \& middle level management representatives and senior level managers. Even though, the research study covered all the managerial positions in the tea industry with the selected sample, it didn't cover the other human resource segments in the industry such as nonexecutive staff and manual workforce which represent more than $90 \%$ of total 
human resource base in the industry. Therefore, to generalize the findings to entire industry, the same research should be repeated as a survey to a larger sample size which covers all the employee categories. A longitudinal study is more suitable since there are a lots of changes taking place in this industry's environment. The same study can be extended to other labour intensive plantation sectors such as rubber and coconut as well as other labour intensive industries.

\section{References}

Ahmad, S. (2013). Paradigms of Quality of Work Life. doi.org/10.1177/097168581247034

Aponso, P. (2000). Adopting technical and human systems for productivity enhancement in manufacturing; Paper presented at the National Convention on Employee Involvement and Employee Involvement Awards, Colombo: Sri Lanka Association for Advancement of Quality and Productivity.

Argyris, C. (1960). Understanding organizational behavior. American Political Science Review, 54(3).

Arunatilake, N. (2000). Effectiveness of Welfare Programmes in Improving Estate Performance in Sri Lanka, Research Studies: Human Resource Development Series, No. 4. Colombo: Institute of Policy Studies.

Arunatilake, N. (2002). The Effect of Housing on Labour Performance in Estates, Colombo: Programme Support Group.

Baily, M. N., Farrell, D., Greenberg, E., Henrich, J. D., Jinjo, N., Jolles, M., \& Remes, J. (2005). Increasing global competition and labor productivity: Lessons from the US automotive industry. McKensie Global Institute, November, 7.

Blau, P.M. (1964). Exchange and power in social life. Social Forces, 44(1), 128-129. Retrieved from https://doi.org/10.2307/2574842.

Bolton, D. (2016). Global Tea Production (2015). http://worldteanews. com/news/global-tea-production-2015.

Bophela, N. R., \& Govender, P. (2015). Employee assistance programs (EAPs): tools for quality of work life. Problems and Perspectives in Management, 13(2), 506-514.

Buunk, B. P. \& Schaufeli, W. B. (1993). Burnout from a social comparison perspective. In W.B. Schaufeli, C. Maslach, T. Marek (Eds). Professional Burnout: Recent Developments in Theory and Research (pp. 53-69). Washington: Taylor \& Francis.

Central Bank of Sri Lanka. (2018). Annual Report. Colombo: Central Bank of Sri Lanka. 
Chernyak-Hai, L \& Rabenu, E. (2018), The New Era Workplace Relationships: Is Social Exchange Theory Still Relevant?, DOI:

https://doi.org/10.1017/iop.2018.5Published online by Cambridge University Press: Access Volume 11, Issue 3, September 2018, 456-481

Cropanzano, R., Anthony, E. L., \& Daniels, S. R. \& Hall, A. V. (2017). Social Exchange Theory: A Critical Review with Theoretical Remedies. The Academy of Management Annals. 11. 1-38. 10.5465/annals.2015.0099.

Cullinane, N., \& Dundon, T, the Psychological Contract: A Critical Review. International Journal of Management Reviews, 8(2), 2006, 113-129.

Dishanka S. \& Ikemoto, Y. (2014). Social Development and Labour Productivity: The Problem and a Solution for the Tea Plantation Sector of Sri Lanka. International Journal of Theory \& Practice, 05(01).

Dissanayake, D.M.R. \& Wanninayake, W.M.C.B. (2010). Positioning Sri Lankan Tea in a Value Added Domain - Challenges and Possible Strategies. Golden Jubilee Commemoration Volume of the University of Kelaniya.

Gamage, A.T. \& Wickramaratne, W.P.R. (2019). Productivity Enhancing Sustainable Human Care and Knowledge Management Practices in Sri Lankan Tea Industry: International Journal of Business and Social Science, 10(8). doi:10.30845/ijbss.v10n8p9.

Ganewatta, G. and G. W. Edwards (2000). The Sri Lanka Tea Industry: Economic Issues and Government Policies, School of Business, La Trobe University, Bundoora, Victoria, Australia, 3083

Gupta, B. (2016). Factors affecting quality of work life among private bank employees. Pacific Business Review International, 8(9), 1-10.

Hill, C., Jones, G., \& Schilling, M. (2014). Strategic management: theory: an integrated approach. Cengage Learning.

Hobfoll, S.E. \& Shirom, A. (2000). Conservation of resources theory: Applications to stress and management in the workplace. In: R.T. Golembiewski (Ed.). Handbook of Organizational Behavior (2nd revised edition; pp. 5781). New York: Marcel Dekker.

Jalal. H (2016). Improving employee productivity through work engagement: Evidence from higher education sector. Management Science Letters, 6, 6170. 10.5267/j.msl.2015.11.006.

Kara, D., Kim, H., Lee, G., \& Uysal, M. (2018). The moderating effects of gender and income between leadership and quality of work life (QWL). International Journal of Contemporary Hospitality Management, 30(3), 1419-1435.

Kelegama, S. (2010). Productivity Decline in the Tea Plantations and a Possible Way Forward. Colombo: VijithaYapa Publications. 
King, W.R. (2007). Knowledge Management: a systems perspective. International Journal of Business and Systems Research, 01(01), 5-28

Kodithuwakku, S., \& Priyanath, H.M.S. (2007). Reasons for the improvement of labour productivity in Tea Plantations after privatization with special reference to the estate laborers in Tea Plantations after privatization with special reference to the estate laborers in Rathnapura district. Sabaragamuwa University Journal, 7(1), 37-47.

Koththagoda,K.C. \& Dissanayake,D.M.R. (2017). Potential of Tea Tourism in Sri Lanka: A Review on Managerial Implications and Research Directions, Equality and Management, University of Szczecin, Poland, 51-68

Kumarasiri, S \& L.D. Wijekoon (2001) 'Development of Estate Worker Housing Cooperative Societies', in H.E.B. Kamphuis \& B. Sivaram (eds) Human Perspectives in the Plantation Sector, Colombo: Programme Support Group.

Lawler, E. J., \& Thye, S. R. (2006). Social exchange theory of emotions [Electronic version]. In J. E. Stets, \& J. H. Turner (Eds.), Handbook of the sociology of emotions (pp. 295-320). New York, NY: Springer Science+Business Media, LLC. doi: 10.1007/978-0-387-30715-2_14 Reprinted with permission. All rights reserved.

Lawler, E. J., \& Thye, S. R. (2006). Social exchange theory of emotions [Electronic version]. Retrieved [insert date], from Cornell University, ILR School site: https://digitalcommons.ilr.cornell.edu/articles/1261

Leitão J, Pereira D, Gonçalves Â. Quality of Work Life and Organizational Performance: Workers' Feelings of Contributing, or Not, to the Organization's Productivity. Int J Environ Res Public Health. 2019;16(20):3803. Published 2019 Oct 10. doi:10.3390/ijerph16203803

Lodha, D., \&Pathak, K. (2017). Effect of psychological contract on employee engagement. Journal of Researchers, 1(1)6-9.

Lowe, G. S. (2000). The Quality of Work Life: A People-Centred Agenda, Oxford University Press.

Masson, R., Royal, M., Agnew, T., \& Fine, S. (2008). Leveraging employee engagement:The practical implications. Industrial and Organizational Psychology, 1(1), 76-59.

Munasinghe, M., Deraniyagala, Y., Dassanayake, N., \&Karunarathna, H. (2017). Economic, social and environmental impacts and overall sustainability of the tea sector in Sri Lanka. Sustainable Production and Consumption, 12, 155169. 
Omotayo, F. O. (2015). Knowledge management as an important tool in organizational management: A review of literature. Library Philosophy and Practice (e-journal). Retrieved from http://digitalcommons.unl.edu.

Pethiyagoda, R (2017). 'Better Tea, Richer People, Business Today 13th March 2017

Rajadurai, R. (2015). Determinants of Annual Productivity of Female Tea Harvesters in the Mid Country Regional Plantation Company Estates in Sri Lanka. Peradeniya: Post Graduate Institute of Agriculture.

Redmond, M. V. (2015). Face and politeness theories. English Technical Reports and White Papers. 2. Retrieved from http://lib.dr.iastate.edu/engl_reports/2.

Rousseau, D. M. (1989). Psychological and Implied Contracts in Organizations. Employee Responsibilities and Rights Journals, 2(2), 121-139.

Rousseau, D. M. (1990). New Hire Perceptions of their Own and their Employer's Obligations: A Study of Psychological Contracts. Journal of Organizational Behaviour, 11, 1990, 389-400.

Sauermann, J. (2016). Performance measures and worker productivity. IZA World of Labor: 260 doi: 10.15185/izawol.260.

Schaufeli, W. B. (2006). The balance of give and take: Toward a Social Exchange Model of burnout, International Journal of Psychology, Grenoble University press, 2006/1, Volume 19, pages 75 -119.

Selvaratnam, R., De Silva, L., Pathmeswaran, A. and de Silva, N. (2011). Nutritional status and productivity of Sri Lankan tea pluckers. Ceylon Medical Journal, 48(4), pp.114-118. DOI: http://doi.org/10.4038/cmj.v48i4.3326

Suri, Disha \& Baber, Ruturaj. (2019). Review Paper on Quality of Work Life. SSRN Electronic Journal. 10.2139/ssrn.3307722.

Swarnathilake, C., Weerahewa, J. and Bandara, Y.M. W. Y. (2019). Productivity Growth in Food Manufacturing Industry: Empirical Evidence from Postreform Sri Lanka. doi.org/10.1177/0972150919884405.

Tessa, S. (2018). The only way is ethics: sustainable tea production. Article published in 'behind the stalls' marketing campaign- Borough Market, London.

Varey, R. J., (2015), Social Exchange (Theory) - Marketing. doi.org/10.1002/9781118785317.

Wal, S. V. D. (2008). Sustainability Issues in the Tea Sector, A comprehensive Analysis of Six Leading Producing Countries, Centre for Research on Multinational Corporations, Amsterdam, Netherlands. 
Gamage \& Wickramaratne, KJHRM 2020, 15(01)

Wijayasiri, J., Arunatilake, N. \& Kelegama, S. (2018). Sri Lanka Tea Industry

Transition: 150 Years and Beyond. Colombo: Institute of Policy Studies of Sri Lanka.

Zin, R. M. (2004). Perception of Professional Engineers toward Quality of Worklife and Organizational Commitment: A Case Study. Gadjah Mada International Journal of Business, 6(3), 323-334. 